\title{
Systematic revision of Macrotingis and phylogenetic analysis of the genera Macrotingis and Ceratotingis (Heteroptera: Tingidae)
}

\author{
SARA ItZel MONTEMAYOR ${ }^{1}$ and Luiz AnTÔNio Alves COSTA² \\ 'División Entomología, Museo de La Plata, Paseo del Bosque S/N, 1900 La Plata, Argentina; \\ e-mail: smontemay@fcnym.unlp.edu.ar \\ ${ }^{2}$ Museu Nacional, Quinta da Boa Vista, Rio de Janeiro 20940-040, Brazil; e-mail: tlcosta@uol.com.br
}

Key words. Heteroptera, Tingidae, phylogenetic analysis, Macrotingis, Ceratotingis, Ceratotingis spatula comb. n.

\begin{abstract}
The Central American genus Macrotingis Champion, 1897 was revised and the morphological characters of the species of Macrotingis and those of its sister group Ceratotingis Montemayor, 2008 were subjected to a phylogenetic analysis. A species previously placed in the genus Tigava is now Ceratotingis spatula (Monte, 1945), new combination. Cladistic analysis indicates that both genera are monophyletic and defined the relationships between species. Keys to the species in these genera are provided together with illustrations of their main morphological characters and a map of their distribution in Central America.
\end{abstract}

\section{INTRODUCTION}

The lace bug genus Macrotingis Champion is restricted to Central America and currently includes M. biseriata Champion, 1897, M. novicis Drake, 1928, M. schaffneri Froeschner, 2003 and M. uniseriata Champion, 1897. Recently Montemayor (2008) erected another Central American genus: Ceratotingis, which includes Ceratotingis zeteki (Drake, 1950), transferred from Macrotingis, and two new species, C. costarriquense Montemayor, 2008 and C. rafaeli Montemayor, 2008, and noted the affinities between these two genera. The most comprehensive study of the genus is that of Froeschner (2003). In this study he describes a new species, M. schaffneri, elevates to species status $M$. novicis and provides a key to the species of Macrotingis.

In the present contribution Tigava spatula is transferred to the genus Ceratotingis, which constitutes the first record of the genus for South America. A comprehensive systematic revision of Macrotingis was carried out, the monophyly of Ceratotingis and Macrotingis confirmed and the relationships between species defined. Illustrations, photographs and a distributional map are provided. A new key to species of Macrotingis is presented, which includes new characters, and a key to species of Ceratotingis is adapted by incorporating C. spatula comb. $\mathrm{n}$.

\section{MATERIAL AND METHODS}

The terminology for the morphology follows Drake \& Davis (1960). Measurements (Table 1) were made using an ocular micrometer and are in millimetres, and "*” is used to indicate the measurement was repeated. When at least five specimens were measured minimum, maximum and mean values are provided; when four or fewer specimens were measured values for each individual are provided. Photographs were taken using a Sony DSC-W7 camera attached to a Wild M-5 stereomicroscope. The specimens studied belong to the Institut Royal des Sciences Naturelles de Belgique, Bruxelles, Belgique (IRSNB); The Museum of Natural History, Smithsonian Institution
(NMNH); The Natural History Museum, London, England $(\mathrm{BMNH})$ and The Museu Nacional de História Natural da Universidade Federal do Rio de Janeiro (MNRJ). The labels of examined specimens were transcribed in the section "Material examined", where "ND" indicates it was impossible to determinate the sex of the specimen.

\section{TAXONOMY}

\section{Genus Macrotingis Champion, 1897}

Macrotingis Champion, 1897: 22; Hurd, 1946: 469; Drake \& Ruhoff, 1960: 66; 1965: 294; Brailovsky \& Torres, 1986: 902; Froeschner, 2003: 31.

Type species. Macrotingis biseriata Champion, 1897 by original designation.

Diagnosis. Antennae longer than body; segment I at least 4 times the length of the head; bases of segment I widely separated; segment IV spatulate; hood well developed, compressed; one long cephalic spine; pronotum with one or three low carinae and lacking areolae; lateral pronotal carinae when present only developed on posterior process; lateral margins of hemelytra serrate, with setae; discoidal area short, not reaching the middle of the hemelytra.

Redescription. Head short, broad. One median, unpaired, long cephalic spine. Bucculae in contact apically, moderately broad. Eyes oval. Rostrum reaching at least the posterior half of mesosternum. Antennae extremely long and slender, at least 1.1 times the length of the body; segment I very long, between 4.4 to 7.1 times the length of the head; segment II short; segment III very long; segment IV spatulate.

Pronotal disc convex, shiny. Collar raised in a high, compressed hood, projected forward. Paranota wide, margins with setae. One or three carinae very low, lateral carinae when present only developed on posterior process. Posterior process long, tapering gradually to a sharp point. Rostral laminae composed of one row of 
TABLE 1. Measurements of species of Macrotingis and Ceratotingis spatula comb. $\mathrm{n}$.

\begin{tabular}{|c|c|c|c|c|c|c|c|c|c|}
\hline & \multicolumn{2}{|c|}{ M. biseriata } & \multicolumn{2}{|c|}{ M. novicis } & \multicolumn{2}{|c|}{ M. schaffneri } & \multirow{2}{*}{$\begin{array}{c}. \\
\text { uniseriata } \\
\delta \mathrm{N}=1\end{array}$} & \multicolumn{2}{|c|}{ C. spatula } \\
\hline & $q \mathrm{~N}=5$ & $\widehat{o} \mathrm{~N}=5$ & ㅇ $\mathrm{N}=4$ & $\sigma \mathrm{N}=3$ & 우 $\mathrm{N}=5$ & $\delta \mathrm{N}=5$ & & 우 $\mathrm{N}=1$ & $\delta \mathrm{N}=1$ \\
\hline $\begin{array}{l}\text { Total } \\
\text { length }\end{array}$ & $\begin{array}{c}5.25-5.66 \\
(5.39)\end{array}$ & $\begin{array}{c}5.19-5.59 \\
(5.41)\end{array}$ & $\begin{array}{c}5.19-5.33 \\
-5.33-5.46\end{array}$ & $\begin{array}{c}5.59-5.13 \\
-5.53\end{array}$ & $\begin{array}{c}5.13-5.46 \\
(5.34)\end{array}$ & $\begin{array}{c}4.93-5.19 \\
(5.08)\end{array}$ & 5.13 & 5.10 & 5.10 \\
\hline $\begin{array}{c}\text { Antennal } \\
\text { seg. I }\end{array}$ & $\begin{array}{c}1.66-1.86 \\
(1.76)\end{array}$ & $\begin{array}{c}1.60-1.82 \\
(1.75)\end{array}$ & $\begin{array}{c}1.76-1.73 \\
-1.82-1.76\end{array}$ & $\begin{array}{c}1.82-1.79 \\
-1.82\end{array}$ & $\begin{array}{c}1.41-1.60 \\
(1.52)\end{array}$ & $\begin{array}{c}1.38-1.44 \\
(1.42)\end{array}$ & 1.50 & 1.40 & 1.50 \\
\hline $\begin{array}{l}\text { Antennal } \\
\text { seg. II }\end{array}$ & $\begin{array}{c}0.16-0.19 \\
(0.18)\end{array}$ & $0.19^{*}$ & $0.16^{*}$ & $0.16^{*}$ & $\begin{array}{c}0.13-0.16 \\
(0.15)\end{array}$ & $\begin{array}{c}0.13-0.16 \\
(0.15)\end{array}$ & 0.19 & 0.10 & 0.10 \\
\hline $\begin{array}{l}\text { Antennal } \\
\text { seg. III }\end{array}$ & $\begin{array}{c}4.00-4.26 \\
(4.16)\end{array}$ & $\begin{array}{c}4.00-4.26 \\
(4.11)\end{array}$ & $\begin{array}{c}4.20-4.26 \\
-4.14-4.20\end{array}$ & $\begin{array}{c}4.20-3.93 \\
-4.00\end{array}$ & $\begin{array}{c}3.53-4.00 \\
(3.89)\end{array}$ & $\begin{array}{c}3.53-3.80 \\
(3.71)\end{array}$ & 3.80 & 3.70 & 3.90 \\
\hline $\begin{array}{l}\text { Antennal } \\
\text { seg. IV }\end{array}$ & $\begin{array}{c}0.80-0.90 \\
(0.85)\end{array}$ & $\begin{array}{c}0.80-0.86 \\
(0.84)\end{array}$ & $\begin{array}{c}0.83-0.74 \\
-0.83-0.83\end{array}$ & $\begin{array}{c}0.86-0.90 \\
-0.90\end{array}$ & $\begin{array}{c}0.67-0.80 \\
(0.68)\end{array}$ & $\begin{array}{c}0.77-0.80 \\
(0.79)\end{array}$ & 0.80 & 0.70 & 0.60 \\
\hline $\begin{array}{l}\text { Head } \\
\text { length }\end{array}$ & $\begin{array}{c}0.29-0.32 \\
(0.31)\end{array}$ & $\begin{array}{c}0.30-0.32 \\
(0.31)\end{array}$ & $\begin{array}{c}0.20-0.29 \\
-0.26-0.29\end{array}$ & $0.29 *$ & $\begin{array}{c}0.29-0.32 \\
(0.30)\end{array}$ & $\begin{array}{c}0.29-0.32 \\
(0.31)\end{array}$ & 0.32 & 0.40 & 0.40 \\
\hline $\begin{array}{l}\text { Pronotum } \\
\text { length }\end{array}$ & $\begin{array}{c}1.92-2.02 \\
(1.96)\end{array}$ & $\begin{array}{c}1.86-2.02 \\
(1.94)\end{array}$ & $\begin{array}{c}1.89-1.98 \\
-1.92-1.95\end{array}$ & $\begin{array}{c}1.92-1.79 \\
-1.86\end{array}$ & $\begin{array}{c}1.79-1.86 \\
(1.82)\end{array}$ & $\begin{array}{c}1.60-1.76 \\
(1.66)\end{array}$ & 1.89 & 2.00 & 1.90 \\
\hline $\begin{array}{l}\text { Pronotum } \\
\text { width }\end{array}$ & $\begin{array}{c}0.96-0.99 \\
(0.98)\end{array}$ & $\begin{array}{c}0.96-0.99 \\
(0.98)\end{array}$ & $\begin{array}{c}0.96-0.96 \\
-0.93-0.90\end{array}$ & $\begin{array}{c}0.93-0.86 \\
-0.93\end{array}$ & $\begin{array}{c}0.93-0.96 \\
(0.94)\end{array}$ & $\begin{array}{c}0.90-0.93 \\
(0.91)\end{array}$ & 0.93 & 1.20 & 1.10 \\
\hline $\begin{array}{l}\text { Hemelytral } \\
\text { length }\end{array}$ & $\begin{array}{c}4.00-4.20 \\
(4.08)\end{array}$ & $\begin{array}{c}4.00-4.26 \\
(4.09)\end{array}$ & $\begin{array}{c}4.00-4.06 \\
-4.13-4.13\end{array}$ & $\begin{array}{c}4.20-3.86 \\
-4.20\end{array}$ & $\begin{array}{c}3.93-4.26 \\
(4.06)\end{array}$ & $\begin{array}{c}3.73-3.93 \\
(3.84)\end{array}$ & 3.86 & 3.70 & 3.80 \\
\hline $\begin{array}{l}\text { Discal area } \\
\text { length }\end{array}$ & $\begin{array}{c}1.41-1.44 \\
(1.43)\end{array}$ & $\begin{array}{c}1.44-1.47 \\
(1.45)\end{array}$ & $\begin{array}{c}1.34-1.31 \\
-1.31-1.47\end{array}$ & $\begin{array}{c}1.47-1.31 \\
-1.38\end{array}$ & $\begin{array}{c}1.28-1.50 \\
(1.43)\end{array}$ & $\begin{array}{c}1.28-1.47 \\
(1.34)\end{array}$ & 1.34 & 1.40 & 1.40 \\
\hline $\begin{array}{l}\text { Discal area } \\
\text { width }\end{array}$ & $\begin{array}{c}0.26-0.29 \\
(0.28)\end{array}$ & $0.29 *$ & $\begin{array}{c}0.29-0.29 \\
-0.29-0.32\end{array}$ & $\begin{array}{c}0.29-0.26 \\
-0.29\end{array}$ & $\begin{array}{c}0.35-0.42 \\
(0.37)\end{array}$ & $\begin{array}{c}0.32-0.35 \\
(0.33)\end{array}$ & 0.26 & 0.30 & 0.30 \\
\hline $\begin{array}{l}\text { Abdominal } \\
\text { length }\end{array}$ & $\begin{array}{c}2.33-2.60 \\
(2.42)\end{array}$ & $\begin{array}{c}2.40-2.60 \\
(2.45)\end{array}$ & $\begin{array}{c}2.37-2.27 \\
-2.37-2.37\end{array}$ & $\begin{array}{c}2.50-2.46 \\
-2.46\end{array}$ & $\begin{array}{c}2.27-2.40 \\
(2.34)\end{array}$ & $\begin{array}{c}2.27-2.37 \\
\quad(2.30)\end{array}$ & 2.27 & 2.60 & 2.40 \\
\hline $\begin{array}{l}\text { Pygophore } \\
\text { length }\end{array}$ & & $\begin{array}{c}0.72-0.77 \\
(0.73)\end{array}$ & & $\begin{array}{c}0.64-0.63 \\
-0.64\end{array}$ & & $\begin{array}{c}0.66-0.68 \\
(0.67)\end{array}$ & & & 0.50 \\
\hline
\end{tabular}

areolae, high, mesosternal laminae more widely separated anteriorly than posteriorly, metasternal laminae closed posteriorly.

Hemelytra narrow, widened distally, extending considerably beyond the apex of abdomen; margins serrated, with setae. Costal area wide, composed of one or two rows of areolae. Subcostal area subvertical, narrow, composed of a variable number of rows of areolae. Discoidal area short, not reaching the middle of the hemelytra. Sutural area narrow, with areolae becoming larger and more irregular posteriorly. Hypocostal area with one row of areolae. Legs yellowish, long, slender.

Discussion. Macrotingis as well as Ceratotingis are closely related to Tigava Stål, a genus distributed in Central and South America. The general appearance of Tigava is very similar to Macrotingis and Ceratotingis. In these three genera the body is long and slender, the legs and antennae are thin and long, and segment I is particularly long. This last character is very infrequent among Tingidae and is a synapomorphy shared by these genera. Macrotingis is the sister group of Ceratotingis and shares, among other characters, antennae longer than the body, segment IV spatulate and cephalic spines long. The main characteristics that distinguish these two genera are the number of cephalic spines and presence of pronotal carinae. Macrotingis has one cephalic spine, the pronotal carinae are low and the lateral carinae are absent or only present on the posterior process, whereas Ceratotingis has three cephalic spines, the pronotal carinae are high and the lateral carinae are present on the pronotum. The main characters that distinguish Tigava from Macrotingis and Ceratotingis are antennae shorter or a little longer than the body, segment IV cylindrical and short cephalic spines.

\section{Key to species of Macrotingis}

1 Lateral pronotal carinae absent, paranota with two or three rows of areolae with those in the outer and inner rows of similar size (Figs 1C, 4C)............... schaffneri

- Lateral pronotal carinae present, paranota with two rows of areolae with those in the outer row bigger than those in the inner row . . . . . . . . . . . . . . . . . . . 2

2 Costal area with only one row of areolae over all its length (Figs 1D, 5D)....................... uniseriata

- Costal area with two rows of areolae over all or part of its

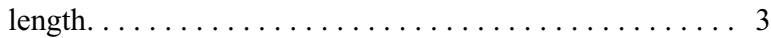

3 Costal area with two rows of areolae over all its length, rostrum reaches the meso-metasternum (Figs 1A, 5A)....... . . . . . . . . . . . . . . . . . . . . . . biseriata

- Costal area with anterior and posterior thirds with one row of areolae, medial third with two, rostrum reaches posterior half of mesoesternum (Figs 1B, 5B).......... M. novicis

\section{Macrotingis biseriata Champion, 1897}

(Figs 1A, 2A, 3A, 4A and 5A)

Macrotingis biseriata Champion, 1897: 22; Froeschner, 2003: 29.

Macrotingis biseriata biseriata: Drake, 1928: 4; Drake \& Ruhoff, 1965: 294.

Diagnosis. Head red brown; rostrum long, reaches the meso-metasternum; pronotal disc with three carinae; paranota with two rows of areolae, areolae in outer row bigger 
than those in inner row; thoracic sterna black; mesosternal rostral laminae converge gradually posteriorly; costal area with two rows of areolae; abdomen bicoloured, pre-genital segments black, genital segments red brown.

Redescription. Total body length (females $\mathrm{N}=5$ and males $\mathrm{N}=5$, respectively): 5.25-5.66 (5.39) 5.19-5.59 (5.41). General colour yellow brown. Head red brown. Cephalic spine slender, erect, covered with disperse, long, erect setae (Figs 2A, 3A). Clypeus reddish brown or dark brown. Bucculae yellow, with three rows of areolae, similar width over all its length. Rostrum yellow except for the brown apex, long, reaches the meso-metasternum. Antennae 1.2 to 1.3 times the length of the body; segment I between 5.0 and 6.1 times the length of the head, with abundant long, semi-erect setae; segment II subconic, glabrous; segment III with abundant long semidecumbent setae and some short semierect setae; segment IV with abundant long, semidecumbent setae and some scattered short, semierect setae.

Pronotal disc red brown, coarsely pitted, three carinae (Fig. 4A). Hood projects as far as anterior half of eyes, surface with long, semi-decumbent scattered setae (Fig. 3A). Callus dark brown, depressed, with abundant long, semidecumbent setae. Paranota sub-vertical, margins serrated with long disperse setae; with two rows of areolae, areolae in outer row bigger than those in inner row. Posterior process yellow. Thoracic sterna black. Rostral laminae: mesosternal laminae convex, maximum separation in anterior third, converge gradually posteriorly; metasternal laminae longer than space separating both laminae.

Hemelytra (Fig. 5A): costal area subhorizontal, with two rows of areolae, areolae big, especially posteriorly. Subcostal area with four rows of medium sized areolae. Discoidal area at widest part with four rows of small areolae.

Abdomen bicoloured, pre-genital segments black, genital segments reddish brown.

Type material examined. Paralectotypes: 19 and 20 , Panama, V. De Chiriqui 25-4000 ft, B.C.A. Rhyn II Macrotingis

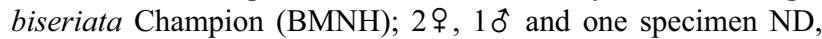
same label (IRSNB); one specimen ND, same label (NMNH). Other material examined. 29 and $2 \hat{\delta}$, Panama, El Valle, Alt. 2000 ft Río Chorros, Quebrada Amarilla, 7.v.1937, R. Bliss, $M$. biseriata det. Champion (NMNH).

Distribution (Fig. 7). Costa Rica (Froeschner, 2003), Honduras (Drake, 1928) and Panama (Champion, 1987).

Discussion. Macrotingis biseriata can be distinguished from the other members of the genus by its very long rostrum, which reaches the meso-metasternal suture, and it's entirely biseriated costal area. In the rest of the species the rostrum reaches the posterior half of the mesosternum and the costal area is uni-biseriated or entirely uniseriated.

\section{Macrotingis novicis Drake, 1928}

(Figs 1B, 2B, 3B, 4B and 5B)

Macrotingis biseriata novicis Drake, 1928: 4; Drake \& Ruhoff, 1965: 294.

Macrotingis novicis: Froeschner, 2003: 29.
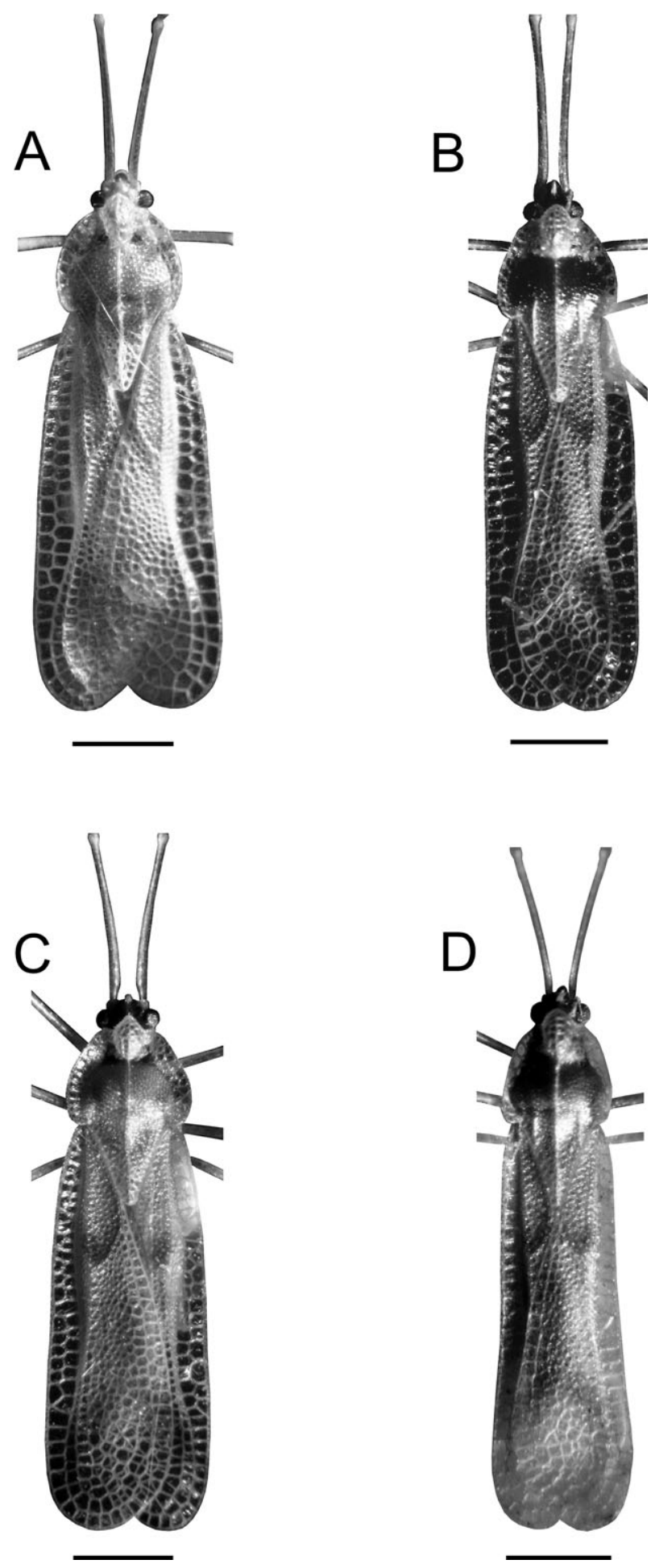

Fig. 1. A-D. Macrotingis species. A - M. biseriata; B $-M$. novicis; C - M. schaffneri; D - M. uniseriata. Scale bar $=1 \mathrm{~mm}$.

Diagnosis. Head black; rostrum moderately long, reaching the posterior half of mesoesternum; pronotal disc with three carinae; paranota with two rows of areolae with those in the outer row bigger than those in the inner row; thoracic sterna black; mesosternal rostral laminae subparallel; costal area with anterior and posterior thirds with one row of areolae, medial third with two; abdomen 
A
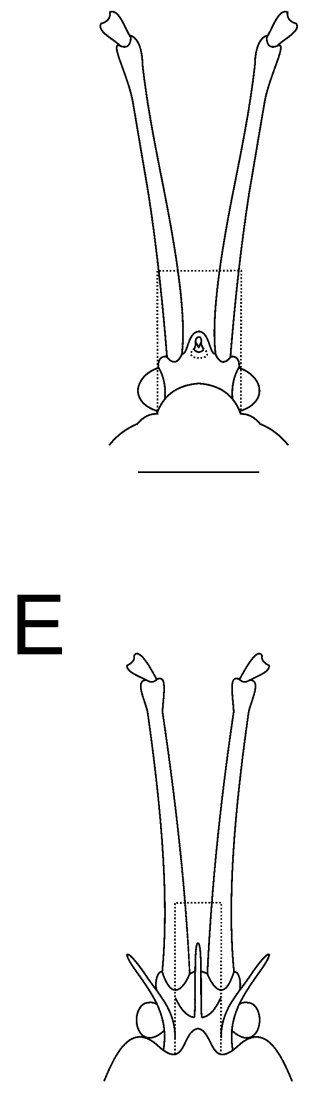
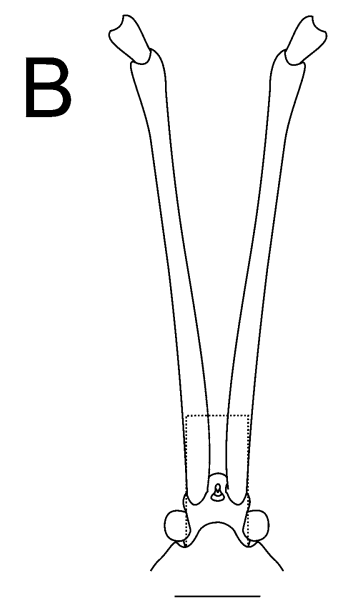

C

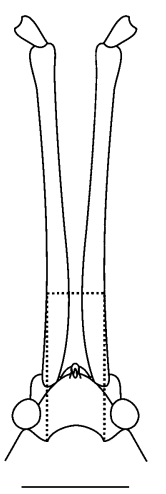

D

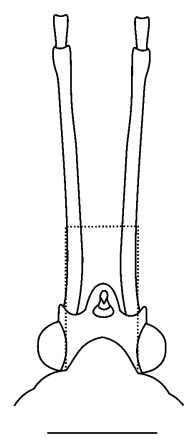

G

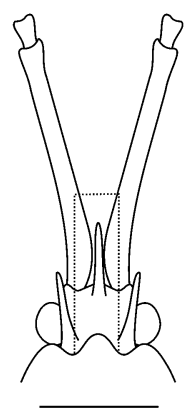

$\mathrm{H}$

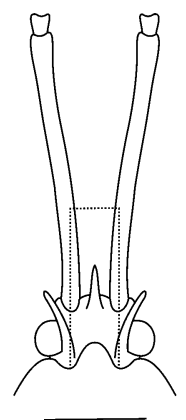

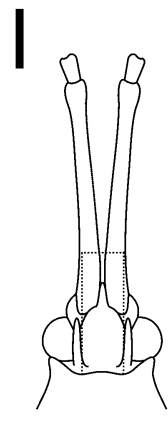
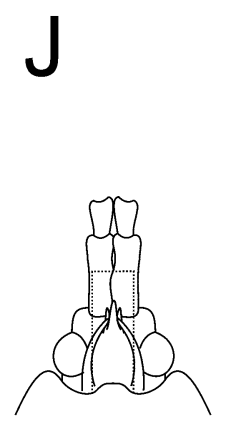

Fig. 2. A-J. Dorsal views of heads of Macrotingis, Ceratotingis, Tigava and Vatiga. A - M. biseriata; B - M. novicis; C - M. schaffneri; D - M. uniseriata; $\mathrm{E}-$ C. costarriquense; F - C. rafaeli; $\mathrm{G}-$ C. spatula $; \mathrm{H}-$ C. zeteki; $\mathrm{I}-$ T. praecellans; J-V. vicosana. Scale bar $=1 \mathrm{~mm}$.

bicoloured, pre-genital segments black, genital segments red brown.

Redescription. Total body length (females $\mathrm{N}=4$ and males $\mathrm{N}=3$, respectively): 5.19-5.33-5.33-5.46 5.59-5.13-5.53. General colour yellow brown. Head black. Cephalic spine slender, erect, covered with dispersed, long, erect setae (Figs 2B, 3B). Clypeus black. Bucculae yellow, with three rows of areolae, posteriorly wider. Rostrum yellow except the brown apex, moderately long, reaching up to posterior half of mesoesternum. Antennae 1.2 to 1.3 times the length of the body; segment I between 6.0 and 7.1 times the length of the head, with short, semierect setae; segment II subconic, with short, semierect setae; segment III with scattered long semidecumbent setae; segment IV with abundant long, semidecumbent setae and some scattered short, semierect setae.

Pronotal disc red brown, coarsely pitted, three carinae (Fig. 4B). Hood projects forwards to middle of eyes, middle line with long, semierect scattered setae (Fig. 3B). Callus dark brown, depressed, with abundant long, semidecumbent setae. Paranota subvertical, margins smooth with long dispersed setae; with two rows of areolae, areolae in outer row bigger than those in inner row. Posterior process yellowish brown. Thoracic sterna black. 


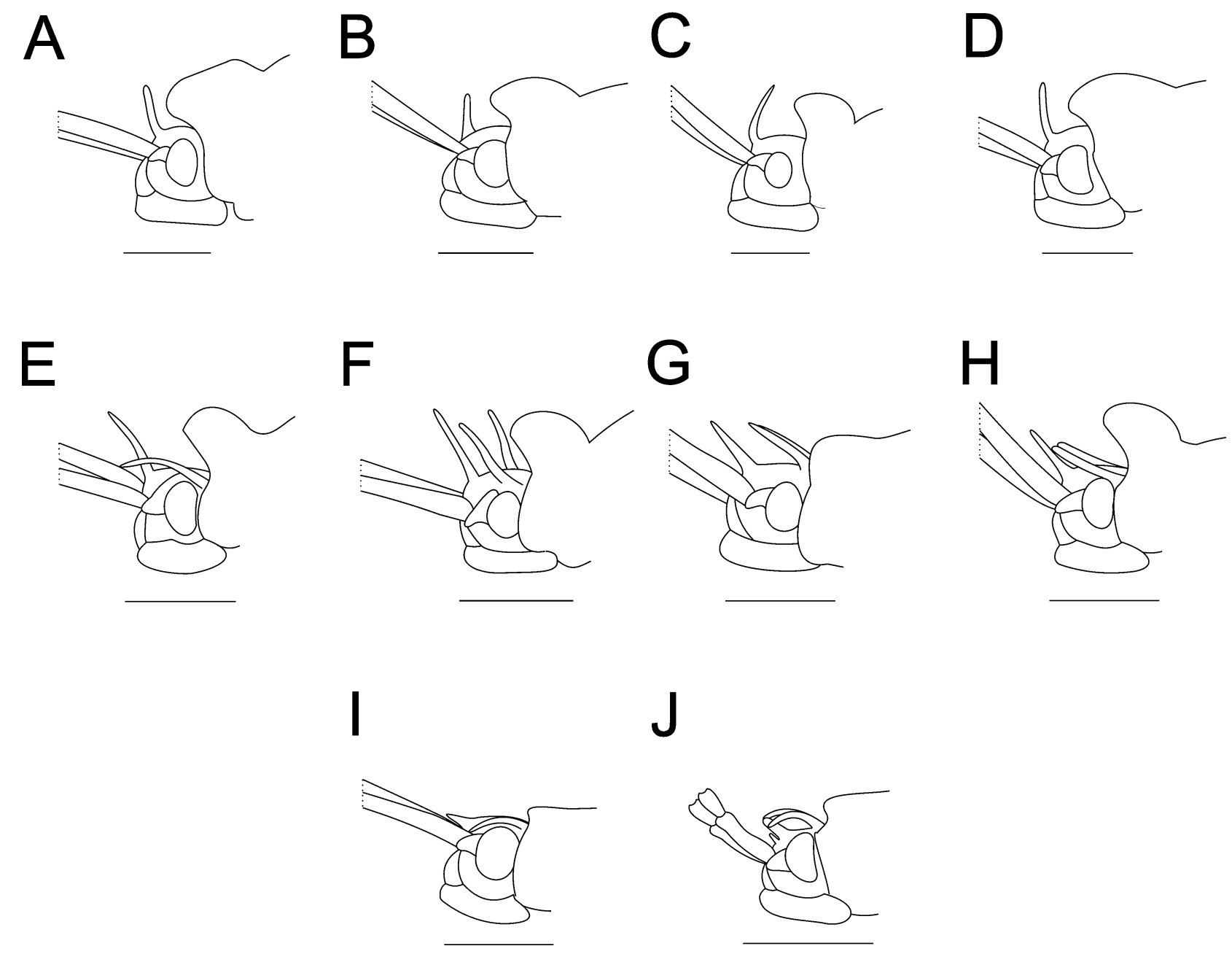

Fig. 3. A-J. Lateral view of heads of Macrotingis, Ceratotingis, Tigava and Vatiga. A - M. biseriata; B - M. novicis; C - M. schaffneri; D - M. uniseriata; $\mathrm{E}-$ C. costarriquense; F - C. rafaeli; $\mathrm{G}-$ C. spatula; $\mathrm{H}-$ C. zeteki; I-T. praecellans; J - V. vicosana. Scale bar $=1 \mathrm{~mm}$.

Rostral laminae: mesosternal laminae subparallel; metasternal laminae as long as space separating both laminae.

Hemelytra (Fig. 5B): costal area subhorizontal, anterior and posterior thirds with one row of areolae, medial third with two, areolae larger posteriorly. Subcostal area with two rows of areolae, areolae of medium size. Discoidal area at its maximum width with five rows of small areolae.

Abdomen bicoloured, pre-genital segments black, genital segments red brown.

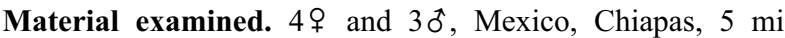
north Nuevo Tenochtitlan, 3000', 7.viii.1990, J.C. Schaeffer (NMNH).

Distribution (Fig. 7). Honduras (Drake, 1928) and México (Froeschner, 2003).

Discussion. This species is very similar to M. biseriata, in fact, it was described as a subspecies of this species until Froeschner (2003) raised to the category of species. Macrotingis novicis can be distinguished from species other than $M$. biseriata by its black thoracic sterna and bicoloured abdomen. It can be distinguished from $M$. biseriata by its black head, uni-biseriated costal area and short rostrum, which only, reaches the posterior half of the mesosternum, and subparallel mesosternal rostral laminae.

\section{Macrotingis schaffneri Froeschner, 2003}

(Figs 1C, 2C, 3C, 4C and 5C)

Macrotingis schaffneri Froeschner, 2003: 31.

Type material examined. Paratypes: $5 q$ and $5 \hat{\sigma}$, Mexico, Oaxaca $2.1 \mathrm{mi}$. Nw. Totolapan, 11.-17.vii.1981, Schaffner (NMNH). Total body length (females $\mathrm{N}=5$ and males $\mathrm{N}=5$, respectively): 5.13-5.46 (5.34) 4.93-5.19 (5.08).

Distribution (Fig. 7). México (Froeschner, 2003).

Discussion. Macrotingis schaffneri has several unique features, such as one pronotal carina and the anterior paranotal margins forming an acute angle with the hood. The rest of the Macrotingis species have three pronotal carinae and the anterior paranotal margins form a right angle with the hood.

\section{Macrotingis uniseriata Champion, 1897}

(Figs 1D, 2D, 3D, 4D and 5D)

Macrotingis uniseriata Champion, 1897: 22; Drake \& Ruhoff, 1965: 294; Froeschner, 2003: 29. 

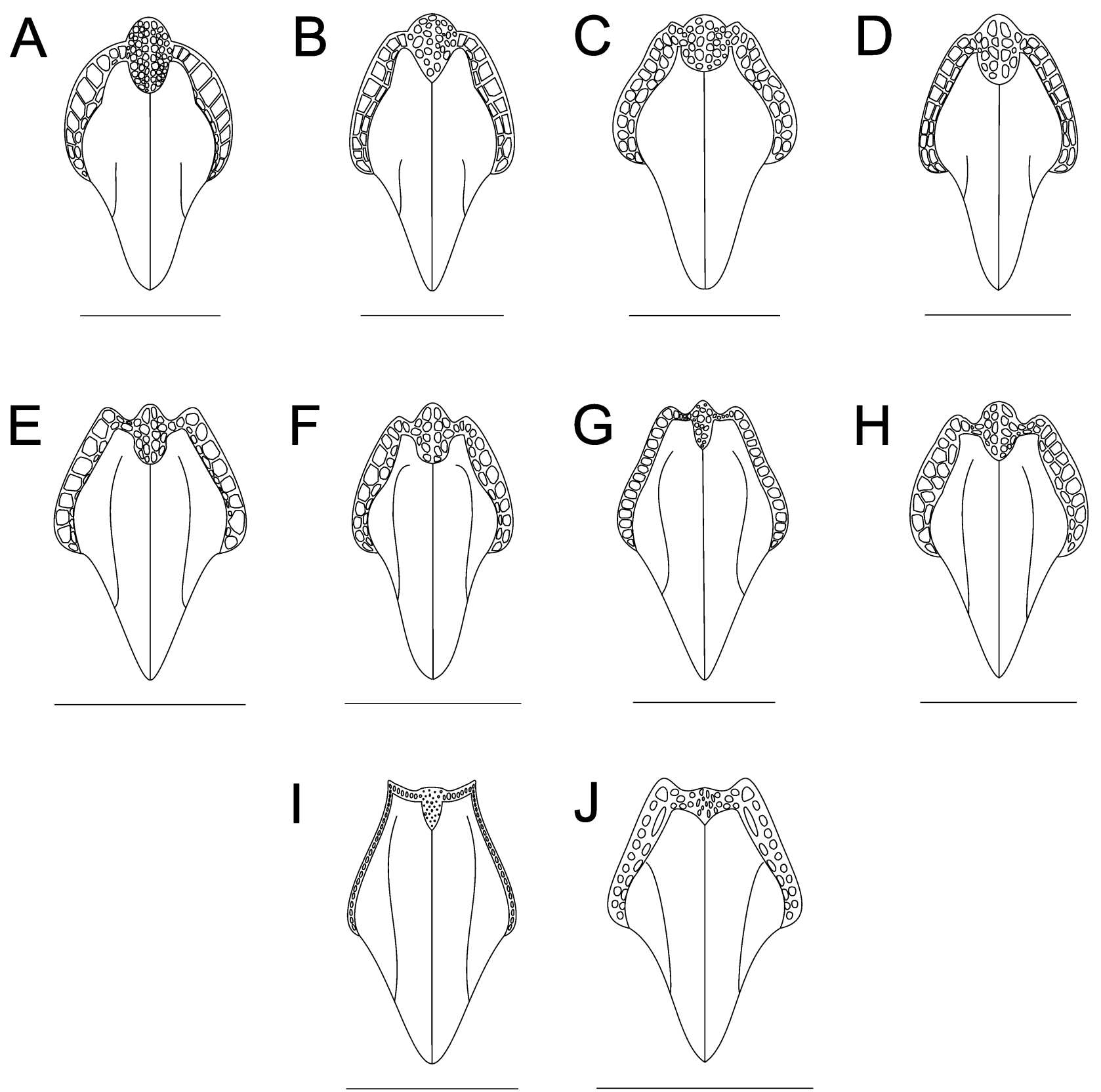

Fig. 4. A-J. Dorsal view of pronotal discs of Macrotingis, Ceratotingis, Tigava and Vatiga. A - M. biseriata; B - M. novicis; C M. schaffneri; D - M. uniseriata; $\mathrm{E}-$ C. costarriquense; $\mathrm{F}-$ C. rafaeli; $\mathrm{G}-$ C. spatula $; \mathrm{H}-$ C. zeteki; I-T. praecellans; J - V. vicosana. Scale bar $=1 \mathrm{~mm}$.

Diagnosis. Head red brown; rostrum moderately long, reaching posterior half of mesosternum; pronotal disc with three carinae; paranota with two rows of areolae with those in the outer row bigger than those in the inner row; sterna on prothorax and metathorax reddish brown and mesothorax black; mesosternal rostral laminae converge gradually posteriorly; costal area with one row of areolae; abdomen unicoloured red brown.

Redescription. Total body length 5.13. General colour yellow brown. Head reddish brown. Cephalic spine slender, erect, glabrus (Figs 2D, 3D). Clypeus dark brown. Bucculae yellow, with three rows of areolae, similar width over all its length. Rostrum yellow except the black apex, moderately long, reaching posterior half of mesoesternum. Antennae 1.2 times the length of the body; segment I 4.5 times the length of the head, with short, semierect setae; segment II subconical, glabrus; segment III with abundant long semierect setae; segment IV with abundant long, semidecumbent setae and some scattered short, semierect setae.

Pronotal disc dark brown, coarsely pitted, three carinae (Fig. 4D). Hood projecting as far as the middle of eyes, glabrus (Fig. 3D). Callus dark brown, depressed, with abundant long, semidecumbent setae. Paranota subvertical, margins serrated, glabrus; with two rows of areolae with those of the outer row bigger than those of the inner row. Posterior process yellowish brown. Pro and metasternum brown, mesosternum black. Rostral laminae: mesosternal laminae converge gradually posteriorly; 

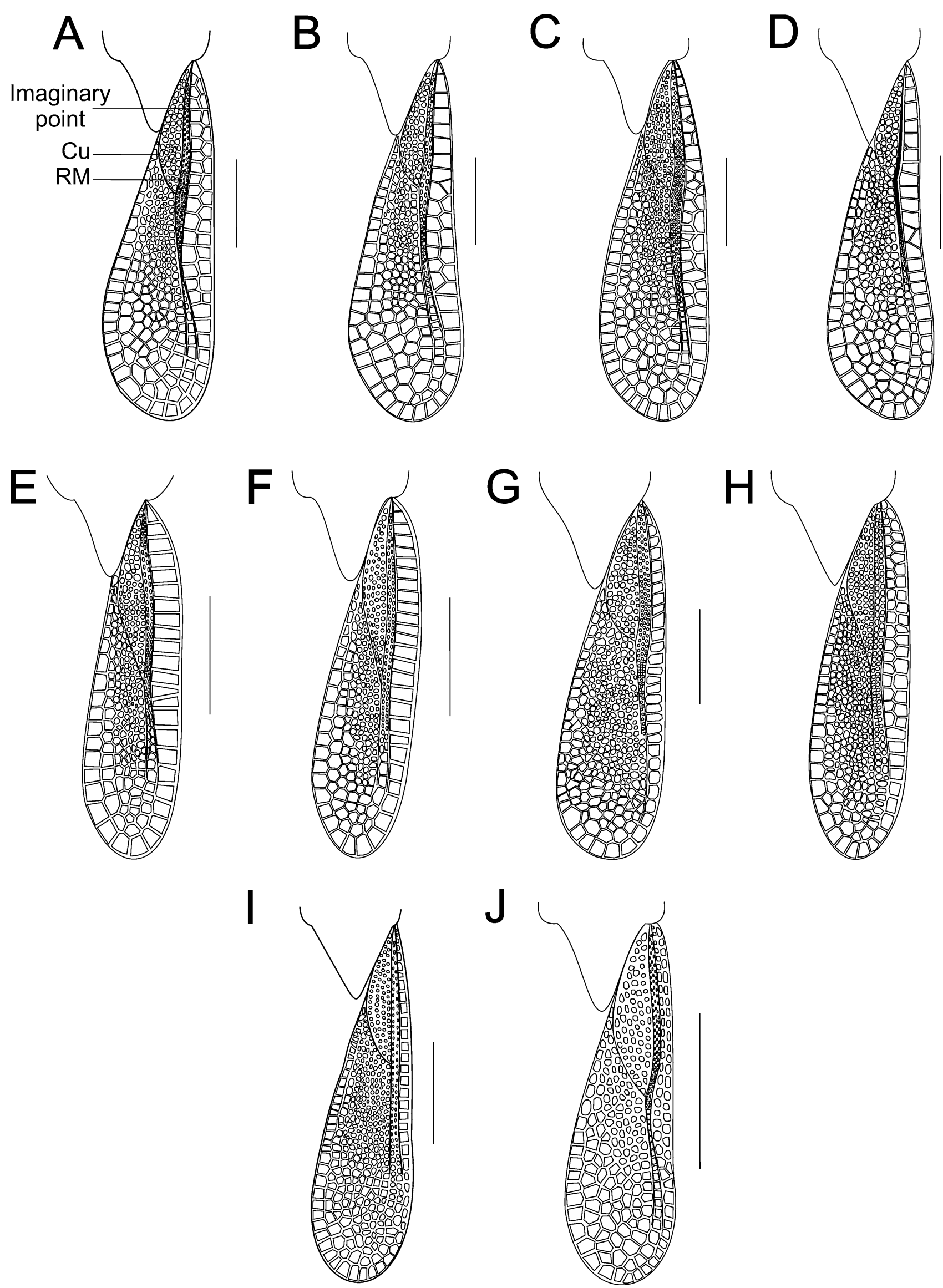

Fig. 5. A-J. Hemelytra of Macrotingis, Ceratotingis, Tigava and Vatiga. A - M. biseriata; B - M. novicis; C - M. schaffneri; D M. uniseriata; $\mathrm{E}-$ C. costarriquense; F - C. rafaeli; $\mathrm{G}-$ C. spatula $; \mathrm{H}-$ C. zeteki; I - T. praecellans; J - V. vicosana. Abbreviations: $\mathrm{Cu}$-Cubitus vein; $\mathrm{RM}-$ Radius Media vein. Scale bar $=1 \mathrm{~mm}$. 
metasternal laminae longer than space separating the laminae.

Hemelytra (Fig. 5D): costal area subhorizontal, with one row of areolae, towards the middle of this area there may be some extra areolae, areolae increase in size posteriorly. Subcostal area with three rows of areolae, areolae small. Discoidal area at its maximum width with three rows of small areolae.

Abdomen unicoloured red brown.

Type material examined. Paralectotype: $1 \hat{0}$, Guatemala, Capetillo, B.C.A, Rhyn. II. Champion (BMNH).

Distribution (Fig. 7). Guatemala (Champion, 1897).

Discussion. Macrotingis uniseriata, like M. novicis and $M$. biseriata, has a pronotum with three carinae and biseriate paranota, and has the same rostral length and unicoloured abdomen as $M$. schaffneri. It can be distinguished from the other members of the genus by its uniseriated costal area and red brown pro and metasternum and black mesosternum.

\section{Genus Ceratotingis Montemayor, 2008}

Ceratotingis Montemayor, 2008: 444.

Type species. Ceratotingis rafaeli Montemayor, 2008 by original designation.

Diagnosis. Antennae longer than body; segment I at least 3 times the length of the head; bases of segment I widely separated, segment IV spatulate; hood well developed, compressed; three cephalic spines, occipital pair very long reaching the bases of segment I; pronotum with three high carinae and areolated; lateral pronotal carinae fully developed; lateral margins of hemelytra serrated and with setae.

\section{Key to species of Ceratotingis}

1 Two rows of areolae on costal area (Figs 5H, 6D). . C. zeteki

- One row of areolae on costal area. .............. 2

2 Median pronotal carinae of same height over its entire length (Fig. 6C) . . . . . . . . . . . C. spatula comb. n.

- Median pronotal carinae hump like.............. 3

3 Cuticle anterodorsal to eyes thicker, raised, yellowish and rugouse; segment I more than five times the length of the head (Fig. 6B). . . . . . . . . . . . . . . . . C. rafaeli

- Cuticle anterodorsal to eyes with same characteristics as the rest of the head; segment I approximately four times the length of the head (Fig. 6A). . . . . . . . C. costarriquense

\section{Ceratotingis costarriquense Montemayor, 2008}

(Figs 2E, 3E, 4E, 5E and 6A)

Ceratotingis costarriquense Montemayor, 2008: 446.

Diagnosis. General colour pale yellow. Cuticle anterodorsal to eyes with same characteristics as the rest of the head. Occipital spines abruptly diverging. Segment I approximately four times longer than the head. Hood well developed. Median pronotal carina hump like. Paranota with two rows of areolae. Mesosternal lamina convex and separated by the same distance throughout their length. Costal area with one row of areolae.

Total body length (female holotype): 4.13.
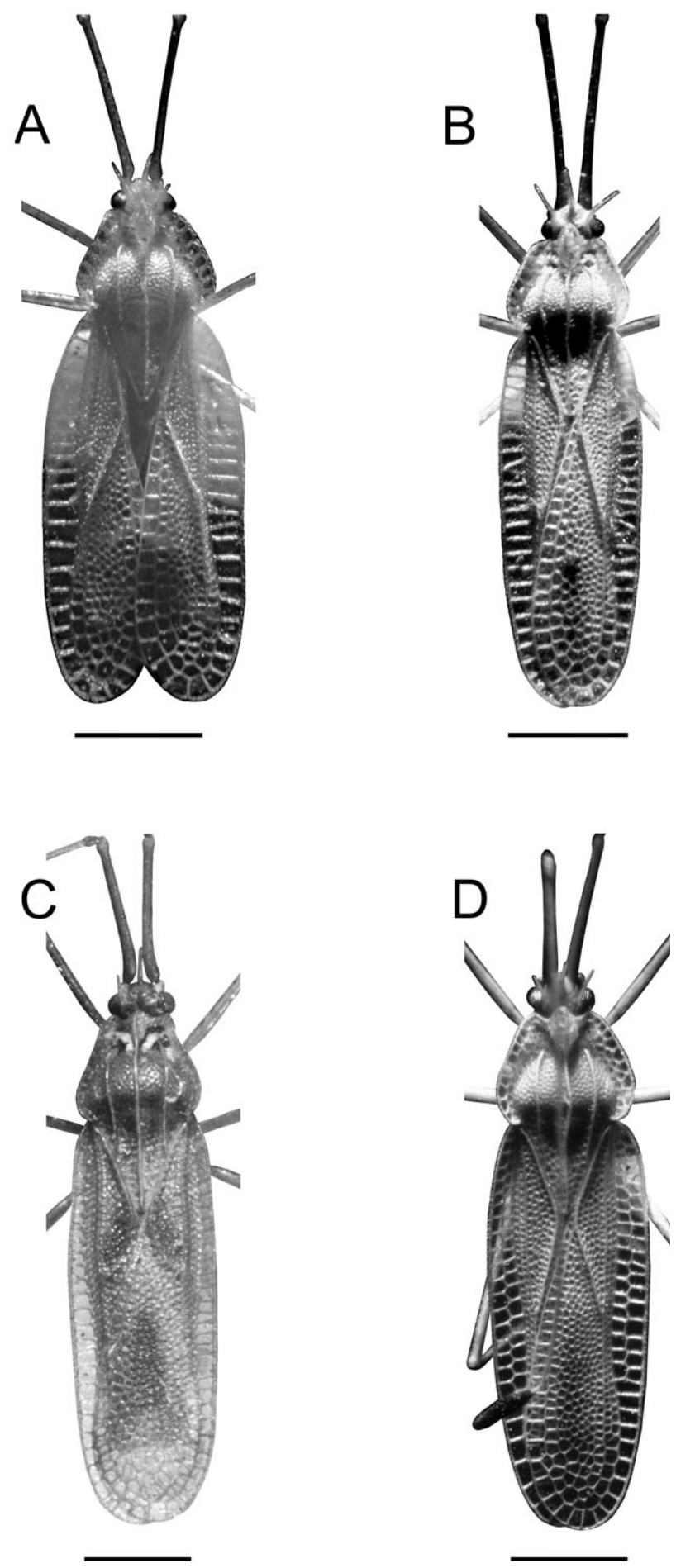

Fig. 6. A-D. Ceratotingis species. A - C. costarriquense; B C. rafaeli; C - C. spatula; D - C. zeteki. Scale bar $=1 \mathrm{~mm}$.

Type material examined. Holotype: $q$, Costa Rica, Turrialba, A.B.S. King coll., 31.i.1978, collected on Phaseolus vulgaris $(\mathrm{NMNH})$.

Distribution (Fig. 7). Costa Rica.

Discussion. Ceratotingis costarriquense like $C$. rafaeli and C. spatula has a uniseriated costal area, but it can be distinguished from $C$. rafaeli by its wider paranota and shorter segment I and from C. spatula by its hump, higher hood and longer discoidal area. 


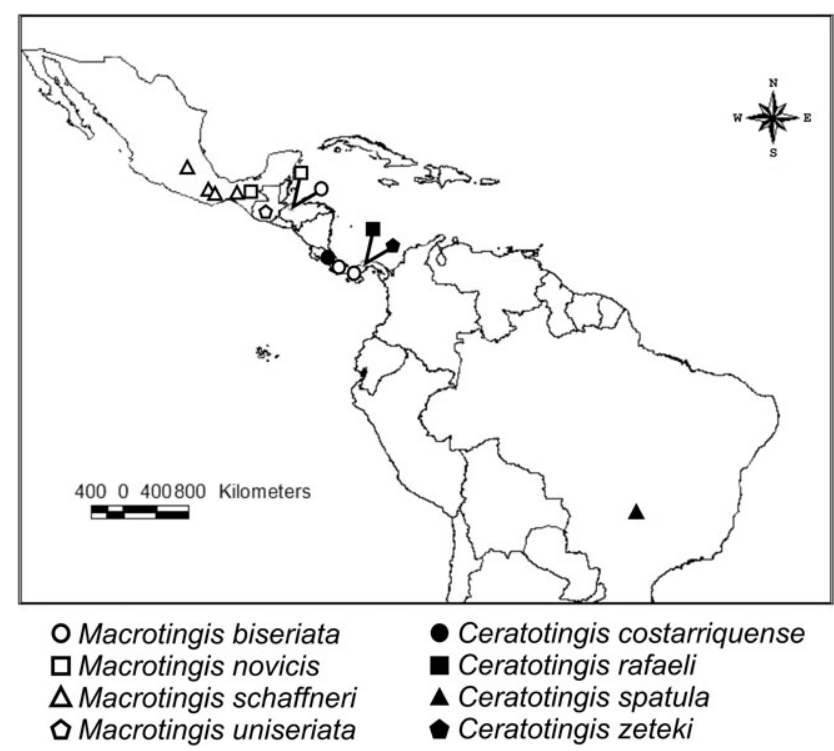

Fig. 7. Geographic distribution of species of Macrotingis and Ceratotingis.

\section{Ceratotingis rafaeli Montemayor, 2008}

(Figs 2F, 3F, 4F, 5F and 6B)

Ceratotingis rafaeli Montemayor, 2008: 444.

Diagnosis. General colour brown. Cuticle anterodorsal to eyes thicker, raised, yellowish and rugose. Occipital spines abruptly diverging. Segment I more than five times longer than the head. Hood well developed. Median pronotal carina in the form of a hump. Paranota with two rows of areolae. Mesosternal lamina convex, both laminae more separated anteriorly than posteriorly. Costal area with one row of areolae.

Total body length (females $\mathrm{N}=5$ and males $\mathrm{N}=5$, respectively): 3.93-4.26 (4.14) 3.93-4.40 (4.21).

Type material examined. Holotype: $\uparrow$, Panama, Colon Province, Y. Basset Coll., 1999, Beating/hand collecting, collected on sapling trees (NMNH). Paratypes six males, eight females, same collecting data (NMNH).

Distribution (Fig. 7). Panama.

Ceratotingis spatula (Monte, 1945) comb. $\mathbf{n}$.

(Figs 2G, 3G, 4G, 5G and 5C)

Tigava spatula Monte, 1945: 250; Drake \& Ruhoff, 1965: 389.

Diagnosis. General colour yellowish brown. Cuticle anterodorsal to eyes with same characteristics as the rest of the head. Occipital spines gradually diverging. Segment I approximately four times longer than the head. Hood moderately developed. Median pronotal carina same height along all its length except at the apex where it is lower. Paranota with one row of areolae. Mesosternal lamina subparallel. Costal area with one row of areolae.

Total body length (male holotype and female paratype, respectively): 5.105 .10 .

Type material examined. Holotype: $\widehat{\jmath}$, Brasil, Goiás, Rio Verde, 19.i.1945, Carvalho col., (MNRJ); Allotype, female, Brasil, Goiás, Rio Verde, 19.i.1945, Carvalho col. (MNRJ).

Distribution (Fig. 7). Brazil (Monte, 1945)
Discussion. Ceratotingis spatula was previously placed in the genus Tigava. The members of the genus Tigava have the bases of segment I adjacent, a cylindrical segment IV, segment I and IV of the same length, median spine is short and directed forwards, occipital spines are subparallel and run close to the surface of the head, a generally short rostrum that does not extend beyond the prosternum, a low hood that scarcely projects over the head and low pronotal carinae.

In C. spatula, like in other species of Ceratotingis, the bases of segment I are widely separated, segment IV is spatuliform, segment I is much longer than segment IV, median spine is long and directed forward, occipital spines form an angle with the surface of the head, the rostrum is long and reaches at least the posterior half of the mesosternum, the hood is well developed, projects over the head and the pronotal carinae are high. Ceratotingis spatula is the sister group of $C$. costarriquense, $C$. rafaeli and C. zeteki; and like the first two species has a uniseriated costa on which, like the latter species, the occipital spines gradually diverge and a median pronotal carina of the same height along its entire length.

Ceratotingis spatula can be distinguished from the rest of the Ceratotingis by its rostrum, which reaches the metasternum, a lower hood, paranota with only one row of areolae, shortness and shape of the discoidal area and the portion of the inner discoidal vein that reaches the subcostal vein is curved whereas in all other Ceratotingis it is rect.

Up to now this is the only species of the genus in South America and there is a large gap in the distribution between the Central American species and C. spatula (Fig. 7). Probably this is a consequence of the lack of field work in this area as the range of the genus should be much wider than that recorded.

\section{Ceratotingis zeteki (Drake, 1950)}

(Figs 2H, 3H, 4H, 5H and 6D)

Macrotingis zeteki Drake, 1950: 299; Drake \& Ruhoff, 1965: 294; Froeschner, 2003: 29.

Ceratotingis zeteki: Montemayor, 2008: 448.

Diagnosis. General colour yellowish brown. Cuticle anterodorsal to eyes with same characteristics as the rest of the head. Occipital spines gradually diverging. Segment I approximately five times longer than the head. Hood well developed. Median pronotal carina same height along its entire length. Paranota with two rows of areolae. Mesosternal lamina subparallel. Costal area with two rows of areolae.

Total body length (male holotype): 4.79 .

Type material examined. Holotype: $\delta$, Panama, Barro Colorado IS., Canal Zone, vii.1946 (NMNH).

Distribution (Fig. 7). Panama.

Discussion. Ceratotingis zeteki can be distinguished from other members of the genus as it has a biseriate costal area. 


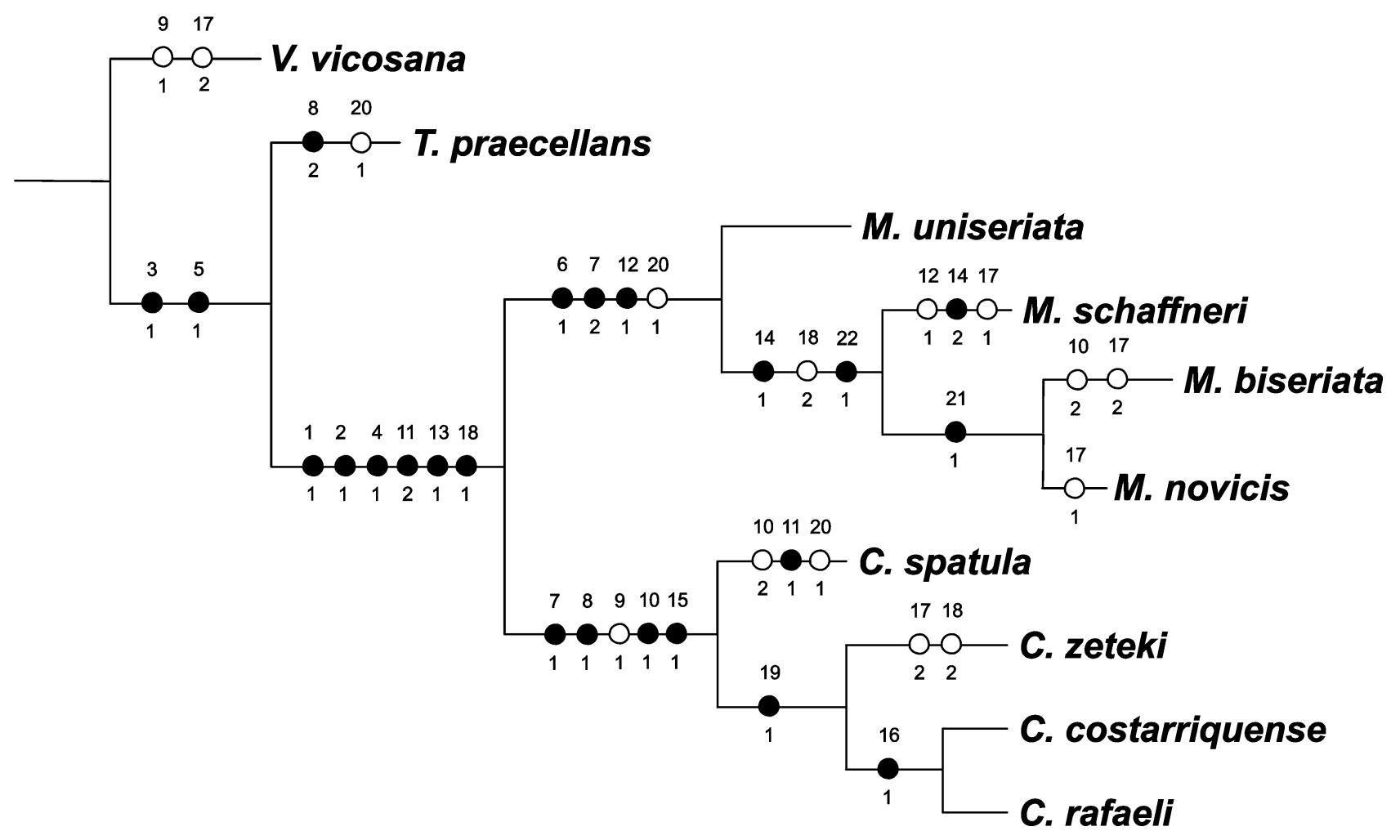

Fig. 8. Single most parsimonious tree (length 41; consistency index, 0.82; retention index, 0.83). Black circles indicate unique changes and white circles homoplasies.

\section{CLADISTIC ANALYSIS}

Phylogenetic analysis was performed on a matrix (Table 2) comprising 21 morphological characters and 10 taxa, five species of Macrotingis, five species of Ceratotingis, one species of Tigava and one of Vatiga. Morphological characters are those of the head, thorax and abdomen, and coloration patterns. Tree searches were performed in TNT (Goloboff et al., 2000). Exact searches were performed by implicit enumeration. All characters were considered to be of equal weight, with multistate characters being treated as unordered. Characters were polarised using the outgroup Tigava praecellans Stål and Vatiga vicosana Drake \& Hambleton.

TABLE 2. Data matrix used in the phylogenetic analysis

\begin{tabular}{ll}
\hline & 0000000001111111111222 \\
& 1234567890123456789012 \\
\hline Vatiga vicosana & 0000000010001000200000 \\
Tigava praecellans & $001010020000000000010 ?$ \\
Macrotingis biseriata & 1111112 ? 2211100220111 \\
Macrotingis novicis & $1111112 ? ? 1211100120111$ \\
Macrotingis schaffneri & $1111112 ? ? 1201200120101$ \\
Macrotingis uniseriata & $1111112 ? ? 1211100010100$ \\
Ceratotingis costarriquense & $111110111120101101100 ?$ \\
Ceratotingis rafaeli & 1111101111201011011000 \\
Ceratotingis spatula & 1111101112100010010100 \\
Ceratotingis zeteki & 1111101111201010221000 \\
\hline
\end{tabular}

\section{RESULTS}

\section{Cladistic analysis}

From the parsimony analysis of the data matrix (Table 2) one most parsimonious tree (Fig. 8) was obtained with a length of 36 , a consistency index of 80 and a retention index of 81 . The analysis recovered Ceratotingis and Macrotingis as monophyletic taxa. Both genera are related and share six character states of the head, prothorax and hemelytra: antennae longer than the body (1:1); segment IV spatulate $(2: 1)$; bases of segment I widely separated $(4: 1)$; rostrum reaching posterior half of mesosternum (9:1); hood well developed (10:2); and medial areolae on costal area subrectangular (17:1).

Ceratotingis was recovered as a monophyletic group based on characters of the head and prothorax: median spine long and porrect $(7: 1)$; occipital spines divergent (8:1); pronotal carinae high (14:1). Within this clade $C$. spatula comb. n., which was previously placed in the genus Tigava, is a sister species of the remaining group, $C$. rafaeli and $C$. costarriquense constitute a clade whose sister species is C. zeteki. Ceratotingis costarriquense and $C$. rafaeli are related by one synapomorphy the presence of a hump on the median pronotal carina (15:1). This last clade is related to $C$. zeteki by one synapomorphy and one homoplasy, these are in order, the distal portion of the cubital vein that reaches the radius media vein is straight (18:1) and the discoidal area is 0.45 or more times the length of the hemelytra (19:0).

The monophyly of Macrotingis is based on characters of the head and prothorax, which are: absence of an 
occipital pair of spines (6:1), median spine long and erect $(7: 2)$ and three pronotal carinae with lateral carinae only on posterior process (13:1). Macrotingis biseriata is closely related to $M$. novicis by one synapomorphy: its bicoloured abdomen (20:1), and one homoplasy: the anterior paranotal margins form a right angle with the hood (11:1). Macrotingis schaffneri is a sister group of the clade made up of $M$. biseriata and $M$. novicis and is related to them by three characters, two synapomorphies and one homoplasy. The two synapomorphies are the unibiseriated costal area (16:1) and a pygopore 0.26 times or more the length of the abdomen (21:1), and the homoplasy is the irregularly shaped medial areolae in the costal area. (17:2). Macrotingis uniseriata is the sister group to the remaining species of the genus.

AKNOWLEDGEMENTS. We would like to thank T. Henry, M. Webb and D. Drugmand for the loan of the material used in this study.

\section{REFERENCES}

Brailovsky H. \& Torres L. 1986: Hemiptera - Heteroptera de México XXXVI. Revisión genérica de la Familia Tingidae Laporte. Ann. Inst. Biol. UNAM 56: 869-932.

Champion G.C. 1897-1901: Insecta: Rhynchota (Hemiptera Heteroptera). In Goodwin F.D. \& Salvin O. (eds): Biologia Centrali-Americana. R.H. Porter, London, pp. 1-48

Drake C.J. 1928: Some Tingitidae (Heteroptera) from Honduras. Occ. Pap. Mus. Zool. Univ. Michigan 190: 1-5.

Drake C.J. 1950: A new tingid from the Canal Zone (Hemiptera). Proc. Entomol. Soc. Wash. 52: 299-300.

Drake C.J. \& Davis N.T. 1960: The morphology, phylogeny, and higher classification of the family Tingidae, including the description of a new genus and species of the subfamily Vianaidinae (Hemiptera: Heteroptera). Entomol. Am. (N.S.) 39: $1-100$.

DraKe C.J. \& Ruhoff F.A. 1960: Lace-bug genera of the world (Hemiptera: Tingidae). Proc. U.S. Nat. Mus. 112: 1-105.

DraKe C.J. \& RuhofF F.A. 1965: Lacebugs of the world: A Catalog (Hemiptera: Tingidae). Bull. U.S. Nat. Mus. 243: $1-634$.

Froeschner R.C. 2003: Review of the Middle American Lace Bug genus Macrotingis (Heteroptera: Tingidae) with a key and a new species from Mexico. Entomol. News 114: 29-32.

Goloboff P. 1999: NONA, Version 2.0. Published by the Author. Tucumán, Argentina.

Goloboff P., Farris S. \& Nixon K. 2000: TNT (Tree Analysis using New Technology). Published by the authors, Tucumán, Argentina.

HuRD M. 1946: Generic classification of North American Tingoidea (Hemiptera - Heteroptera). Iowa State Coll. J. Sci. 20: 429-492.

Monte O. 1945: Trés novos tingitideos. Rev. Entomol. 16: 249-252.

Montemayor S.I. 2008: A new genus and two new species of Tingidae (Heteroptera) from Central America. Zool. Sci. 25: 444-450.

NixON K.C. 2002: Winclada, Version 1.00.08. Published by the author, Ithaca, N.Y.

Received March 2, 2009; revised and accepted April 6, 2009

APPEndix 1. List of the characters.

\section{Head}

1. Antennal length: same length or shorter than body (0); Longer than body (1). In the genera Ceratotingis and Macrotingis the antennae are extremely long, a peculiarity not commonly exhibited by other Tingidae. The antennae of $V$. vicosana are shorter than the body and in $T$. praecellans are the same length as the body.

2. Shape of segment IV: cylindrical (0); spatulate (1). Generally segment IV in Tingidae is cylindrical but in the species of Macrotingis and Ceratotingis it is spatulate.

3. Length of segment I compared to that of segment IV: shorter than segment IV (0); more than 1.5 times longer than segment IV (1). In $V$. vicosana segment I is approximately half the length of segment IV whereas in the other species included in the analysis segment I is much longer than segment IV.

4. Bases of segment I: adjacent (0); widely separated (1). In both $V$. vicosana (Fig. 2J) and T. praecellans (Fig. 2I) the bases of segment I are adjacent to one another, but in all the species of Macrotingis (Fig. 2A-D) and Ceratotingis (Fig. 2E-H) the bases are widely separated.

5. Frontal pair of cephalic spines: present (0), absent (1). Vatiga vicosana (Fig. $2 \mathrm{~J}$ ) is the only species that has a frontal pair of spines, all the other species included in the analysis do not posses these spines. The presence of numerous cephalic spines is considered a plesiomorphic character. Among the Tingidae the members of the most primitive subfamily, Cantacaderinae, always have more cephalic spines than members of the subfamily Tinginae.

6. Occipital pair of cephalic spines: present (0), absent (1). Vatiga vicosana (Fig. 2J), T. praecellans (Fig. 2I) and all the members of the genus Ceratotingis (Fig. 2E-H) have a pair of occipital spines; species of Macrontingis (Fig. 2A-D) do not have a pair of occipital spines.

7. Length and direction in which the median spine points: short and directed forward (0); long and directed forward (1); long and erect (2). The median spine can be short and directed forward as in $V$. vicosana (Fig. 3J) and T. praecellans (Fig. 3I), long and directed forward as in all the members of the genus Ceratotingis (Fig. 3E-H) or long and erect as in species of Macrotingis (Fig. 3A-D).

8. Occipital spines either converge (0), diverge (1) or are subparallel (2). In all species of Ceratotingis (Fig. 2E-H) the occipital spines diverge, in $V$. vicosana (Fig. 2J) they converge and in T. praecellans (Fig. 2I) they are subparallel. The species of Macrotingis do not have occipital spines so the character was coded as "?".

9. Angle between the occipital spines and surface of the head: narrow angle with spines running parallel to surface of head surface (0); wide angle with spines at an angle to the surface of the head (1). In V. vicosana (Fig. 3J) and species of Ceratotingis (Fig. $3 \mathrm{E}-\mathrm{H}$ ) the occipital spines are at an angle to the surface of the head and in T. praecellans (Fig. 3I) they run parallel to the surface of the head. Species of Macrotingis lack occipital spines so the character was coded as "?".

10. Rostral length: not surpassing anterior half of mesosternum (0); reaching posterior half of mesosternum (1); reaching or surpassing posterior margin of meso-metasternum (2). In $V$. vicosana and $T$. praecellans the rostrum is short and does not surpass the anterior half of the mesosternum, in the species other than M. biseriata and C. spatula the rostrum reaches the posterior half of the mesosternum. Macrotingis biseriata and C. spatula have a very long rostrum, in the first species it reaches the posterior margin of the meso-metasternum and in the second species the metasternum. 


\section{Thorax}

11. Degree of development of the hood: slightly developed (0); moderately developed (1); well developed (2). The hood is slightly developed in $V$. vicosana (Fig. $3 \mathrm{~J}$ ) and $T$. praecellans (Fig. 3I), moderately developed in C. spatula (Fig. 3G) but not as well developed as in the rest of the species analyzed (Fig. 3A, B, C, D, E, F, H).

12. Anterior paranotal margins: form an acute angle with the hood (0); form a right angle with the hood (1). In most of the species analyzed (Fig. 4C, E, F, G, H, I, J) the anterior paranotal margins form an acute angle with the hood. The species in which the anterior paranotal angles form a right angle with the hood are M. biseriata (Fig. 4A), M. novicis (Fig. 4B) and M. uniseriata (Fig. 4D).

13. Maximum number of rows of areolae on paranota: one (0); two (1). Tigava praecellans (Fig. 4I) and C. spatula (Fig. 4G) have one row of areolae on the paranota and the other species a maximum of two rows.

14. Number of pronotal carinae: three all well developed (0); three with lateral carinae only on posterior process (1); one (2). Vatiga vicosana (Fig. 4J), T. praecellans (Fig. 4I) and all the species of Ceratotingis (Fig. 4E-H) have three well developed pronotal carinae. In the genus Macrotingis there is a tendency for the lateral carinae to be less well developed as in $M$. biseriata (Fig. 4A), M. novicis (Fig. 4B) and M. uniseriata (Fig. 4D) these carinae are only present on the posterior process and in M. schaffneri (Fig. 4C) are absent.

15. Height of pronotal carinae: low (0); high (1). All the species studied have one row of areolae on the pronotal carinae and in most of these species the pronotal carinae are low with small areolae but in species of Ceratotingis the carinae are high and the areolae are big.

16. Hump on median pronotal carina: absent (0); present (1). In C. costarriquense and C. rafaeli there is a hump on the median pronotal carina, whereas in the other species it is the same height along its entire length.

17. Number of rows of areolae on the costal area: uniseriated (0); uni-biseriated (1); biseriated (2). The species that have only one row of areolae on the costal area are: $T$. praecellans (Fig. 5I), C. costarriquense (Fig. 5E), C. rafaeli (Fig. 5F), C. spatula (Fig. 5G) and M. uniseriata (Fig. 5D). Macrotingis novicis (Fig. 5B) and M. schaffneri (Fig. 5C) have one row on some sections with two on others. Vatiga vicosana (Fig. $5 \mathrm{~J}$ ), C. zeteki (Fig. 5H) and M. biseriata (Fig. 5A) have two rows of areolae on the costal area.

18. Shape of the medial areolae on the costal area: regular subquadrangular (0); regular subrectangular (1); irregular (2). Most of the species studied have regular shaped medial areolae on the costal area but in $V$. vicosana (Fig. 5J) and $T$. praecellans (Fig. 5I) they are subquadrangular and in $C$. costarriquense (Fig. 5E), C. rafaeli (Fig. 5F), C. spatula (Fig. $5 \mathrm{G}$ ) and M. uniseriata (Fig. 5D) subrectangular. In M. biseriata (Fig. 5A), M. novicis (Fig. 5B), M. schaffneri (Fig. 5C) and $C$. zeteki (Fig. $5 \mathrm{H}$ ) the medial areolae are irregularly shaped.

19. Distal portion of Cubitus $(\mathrm{Cu})$ vein: curved (0); straight (1). In most of the species analyzed (Fig. 5A-B, G, I, J) the distal portion of the $\mathrm{Cu}$ vein that reaches the Radius Media vein (RM) is curved. In the case of C. costarriquense (Fig. 5E), $C$. rafaeli (Fig. 5F) and C. zeteki (Fig. $5 \mathrm{H})$ it is straight.

20. Length of discoidal area: 0.45 or more times the length of the hemelytra $(0) ; 0.40$ or less times the length of the hemelytra (1). The discoidal area is long, 0.45 or more times the length of the hemelytra in $V$. vicosana, $C$. costarriquense, $C$. rafaeli and $C$. zeteki, and short, 0.40 or less times the length of the hemelytra in all the species of Macrotingis, T. praecellans and C. spatula.

\section{Abdomen}

21. Abdomen: unicoloured (0); bicoloured (1). Of the species studied only two have a bicoloured abdomen: M. biseriata and $M$. novicis, in both these species the pre-genital segments are black and the genital segments reddish brown.

22. Length of pygophore relative to total abdominal length: 0.23 times or less the abdominal length (0); 0.26 times or more the abdominal length (1). The three species that have a pygopore that is 0.26 times or more the abdominal length are M. biseriata, M. novicis and M. schaffneri, whereas in all the other species it is 0.23 times or less the abdominal length. For $T$. praecellans and C. costarriquense the character was coded as "?" because we were only able to study female specimens. 